\title{
Controlled Trial of Pyrimethamine in Pregnant Women in an African Village
}

\author{
DAVID MORLEY,* $\dagger$ M.D., D.C.H.; MARGARET WOODLAND,* S.R.N. \\ W. F. J. CUTHBERTSON, $\ddagger$ PH.D.
}

Brit. med. F., 1964, 1, 667-668

A longitudinal study of consecutively born African children, beginning in 1957, has been undertaken from a dispensary in the village of Imesi, 100 miles $(160 \mathrm{~km}$.) north-east of Ibadan, in Nigeria. The observations began during the pregnancy of the mother, continued till the child reached its fifth birthday, and were particularly concerned with the effects of frequent infections and poor nutrition. Preliminary investigations had suggested that these factors were primarily responsible for the high mortality in infancy and early childhood.

The stillbirth rate is about 40 per 1,000 total births, and the neonatal death rate and the infant mortality rate 105 and 295 respectively per 1,000 live births (Morley, 1963). It was estimated that about half the children born alive died before their fifth birthday. Satisfactory maternal mortality rates are not available. There were no deaths among the 504 women in this study, but adequate antenatal and maternity care was available.

This paper describes the effect on the mother during pregnancy, and on the newborn child, of one or other of two forms of antimalarial treatment. One group of mothers was given regular monthly dosage of pyrimethamine for the suppression of malaria, and treatment with chloroquine on contraction of any fever not obviously due to acute bacterial infections; the other, the control group, was given placebo tablets (lactose) at monthly intervals and treated with chloroquine on the appearance of fever, as for the first group.

\section{Investigation}

Background to Study.-Imesi lies 600 metres (2,000 feet) above sea-level in a small plateau among hills, north-east of the town of Ilesha. Surveys have shown this to be a holoendemic area for malaria, as is most of Southern Nigeria; the majority of infections are due to Plasmodium falciparum, and few, if any, mothers and children are protected by anti-mosquito or antimalarial measures. There is ample opportunity for mosquito-breeding in the village in water-storage pots and in the 12 streams and pools used as sources of water. The population of just under 5,000 is Yoruba. The majority farm and produce yam, maize, and cassava, with cocoa as the principal cash crop.

Design of Trial.-As the pregnant women were registered at the dispensary they were given consecutive numbers and allotted to one or other of two groups. There were 504 mothers pregnant in the village during the 20 months at the beginning of the survey, but 72 of them failed to attend for antenatal care and three left the village. Of 429 who attended, 217 were in the pyrimethamine group and 212 in the control group. All women with even numbers were given two tablets $(50 \mathrm{mg}$.) of pyrimethamine once a month. If the mother attended the village dispensary with fever, a single dose of $600 \mathrm{mg}$. of chloroquine sulphate was given, this being the dosage advised by Covell, Coatney, Field, and Singh (1955). The control group (the odd numbers) were given two tablets of lactose once a month. Chloroquine sulphate was also given, as in the first

* Child Health Unit of the West African Council for Medical Research, Wesley Guild Hospital, Ilesha, W. Nigeria.

t Now Lecturer in the Department of Human Nutrition in the London School of Hygiene and Tropical Medicine. ₹ Glaxo Research Limited, Greenford, England. group. Blood films were examined in the hospital laboratory by locally trained technicians, and spot checks of a proportion of the films were made by one of us (D. M.). The technicians did not know to which group a mother belonged.

\section{Results}

Pregnancy.-The records of 429 pregnancies and their outcome were studied to determine the effects of giving pyrimethamine. One of the observations made was the small gain in weight of the women during pregnancy. The changes in weight of 164 pregnant women who attended regularly from early pregnancy in the two groups were analysed, the results being set out in Table I. Further details of the gains in weight are being prepared for publication. Table I shows that the women who received pyrimethamine as a malaria suppressant gained more in weight during pregnancy than those receiving antimalarial therapy only when they attended the dispensary with fever. The mean difference between the two groups was $1 \mathrm{lb}$. $14 \mathrm{oz}$. (852 g.), which is statistically significant $(P<0.05)$. The mothers giving birth to boys gained more weight, in both groups, than those giving birth to girls. This difference just

TABLE I.-Mean Weight Gains of Mothers Receiving Pyrimethamine or Lactose During Pregnancy

\begin{tabular}{|c|c|c|c|c|c|c|}
\hline \multirow{2}{*}{ Treatment } & \multirow{2}{*}{$\begin{array}{l}\text { Sex } \\
\text { of } \\
\text { Child }\end{array}$} & \multirow{2}{*}{$\begin{array}{c}\text { No. } \\
\text { of } \\
\text { Mothers }\end{array}$} & \multicolumn{2}{|c|}{ Mean Weight (kg.) } & \multicolumn{2}{|c|}{ Weight Gain } \\
\hline & & & At $16-20$ weeks & At Term & Kg. & lb. oz. \\
\hline \multirow{2}{*}{$\begin{array}{l}\text { Pyrimeth- } \\
\text { amine }\end{array}$} & $\stackrel{M}{M}$ & $\begin{array}{l}41 \\
45\end{array}$ & $\begin{array}{l}52.32 \\
53.94\end{array}$ & $\begin{array}{l}56.44 \\
57.91\end{array}$ & $\begin{array}{l}4 \cdot 12 \\
3.97\end{array}$ & $\begin{array}{ll}9 & 1 \\
8 & 12\end{array}$ \\
\hline & Total & 86 & $53 \cdot 17$ & $57 \cdot 20$ & 4.03 & 814 \\
\hline \multirow{2}{*}{ Lactose } & $\stackrel{M}{\mathrm{M}}$ & $\begin{array}{l}30 \\
48\end{array}$ & $\begin{array}{l}54 \cdot 31 \\
53 \cdot 31\end{array}$ & $\begin{array}{l}57.91 \\
56.21\end{array}$ & $\begin{array}{l}3.60 \\
2.90\end{array}$ & $\begin{array}{l}7 \\
76 \\
6\end{array}$ \\
\hline & Total & 78 & $53 \cdot 68$ & 56.86 & $3 \cdot 18$ & 70 \\
\hline Grand total & & 164 & $\begin{array}{c}53.42 \\
\text { (117 1b. } 10 \frac{1}{2} \text { oz.) }\end{array}$ & $\begin{array}{c}57.04 \\
\text { (125 } \mathrm{lb} .10 \mathrm{oz} .)\end{array}$ & 3.62 & 80 \\
\hline
\end{tabular}

Mean gain in weight of mothers delivering boys was $450 \mathrm{~g}$. (1 lb.) more than that of those delivering girls $(P<0.05)$

Mean gain in weight of mothers receiving pyrimethamine was $852 \mathrm{~g} .(1 \mathrm{lb} .14 \mathrm{oz}$. more than that of control mothers receiving lactose $(P<0.05)$.

TABLE II.-Mean Birth Weight of Children Born to Mothers Receiving Pyrimethamine or to Mothers Receiving Lactose Placebos (Control Group)

\begin{tabular}{|c|c|c|c|c|}
\hline $\begin{array}{l}\text { Sex of } \\
\text { Infant }\end{array}$ & Parity of Mothers & $\begin{array}{l}\text { Pyrimethamine } \\
\text { Group } \\
\text { (g.) }\end{array}$ & $\begin{array}{c}\text { Control } \\
\text { Group } \\
\text { (g.) }\end{array}$ & $\begin{array}{l}\text { Difference } \\
\text { (g.) }\end{array}$ \\
\hline \multirow[t]{2}{*}{ Boys } & $\begin{array}{l}0 \\
1 \text { to } 3 \\
4+\end{array}$ & $\begin{array}{l}2,854(14) \\
2,958(47) * * \\
3,076(40)\end{array}$ & $\begin{array}{l}2,772(10) \\
2,886(36) \\
2,827(39)\end{array}$ & $\begin{array}{r}82 \\
72 \\
249 \\
\end{array}$ \\
\hline & $\begin{array}{l}\text { Mean weight and total } \\
\text { births }\end{array}$ & $2,989(101)$ & $2,846(85)$ & 143 \\
\hline \multirow[t]{2}{*}{ Girls } & $\begin{array}{l}0 \\
1 \text { to } 3 \\
4+\end{array}$ & $\begin{array}{l}2,681(13) * * \\
2,865(46) * \\
3,059(36) *\end{array}$ & $\begin{array}{l}2,473(18) \\
2,816(54) \\
2,814(39)\end{array}$ & $\begin{array}{r}208 \\
49 \\
245\end{array}$ \\
\hline & $\begin{array}{l}\text { Mean weight and total } \\
\text { births }\end{array}$ & $2,915(95)$ & $2,759(111)$ & 156 \\
\hline \multicolumn{2}{|c|}{ Overall mean weights and total births } & $\begin{array}{l}2,954(196) \\
(6 \mathrm{lb} .8 \text { oz.) }\end{array}$ & $\begin{array}{l}2,797(196) \\
\left(6 \text { lb. } 2 \frac{1}{2} \text { oz. }\right)\end{array}$ & $\begin{array}{c}157 \\
\text { (st } 02 .)\end{array}$ \\
\hline
\end{tabular}

Difference in mean birth weight between pyrimethamine and lactose groups of $157 \mathrm{~g} .\left(5 \frac{1}{2}\right.$ oz.) was significant $(\mathrm{P}<0.05)$.

Figures in parentheses denote numbers of single births and not number of weights ecorded.

Indicates that the birth weight of one infant was not recorded. 
achieves statistical significance, but because no explanation can be offered for it further investigation is required to determine whether or not it may have occurred by chance alone.

Birth Weight.-The suppression of malaria in pregnancy was thought likely to have some effect on the mean birth weight of the children. In Table II the effects of treatment and the parity of mothers on the mean birth weights of live-born singletons from 402 mothers are shown; 17 stillbirths and 10 twin deliveries have been excluded. Mothers who took pyrimethamine, even if irregularly, gave birth to babies that weighed on average $157 \mathrm{~g}$. $\left(5 \frac{1}{2} \mathrm{oz}\right.$.) more than those in the control group. A further analysis of the control group did not demonstrate a difference between those receiving occasional treatment with chloroquine and those who had lactose alone.

Stillbirths and Neonatal Deaths.-The results of this trial showed no difference in the overall stillbirth and neonatal death rates among the singletons born to the mothers in the pyrimethamine and lactose groups (14/210 and 13/209 respectively). However, if the mothers who attended for antimalarials regularly are separated, there were found to be 138 mothers with only six stillbirths and neonatal deaths. These results do not reach statistical significance $(P=0.05)$. Failure to demonstrate a statistical difference in mortality may be due to the small numbers involved and because any mother presenting with fever in either group was promptly given chloroquine.

Maternal Blood Films.-The results of examining blood films from 237 mothers are available, these being mothers who made an initial and at least one subsequent visit to the antenatal clinic. Of the films taken at the initial visit $46(19 \%)$ showed malarial parasites. Of the 119 mothers given pyrimethamine, $21 \mathrm{com}-$ plained of fever ; none of the films taken during the period of fever showed parasites. Of the 108 given lactose, 45 complained of fever on 57 occasions ; 14 of the films taken on those occasions showed parasites.

Placenta.-When examining placentas infected with malarial parasites, it was noticed that a macroscopic change was evident. The infected placenta was often darker than a normal placenta. It was thought possible that such infected placentas might weigh less than a normal placenta, and that this might be responsible for part of the increase in weight of the pregnant mothers receiving pyrimethamine. The placentas from 137 mothers were weighed. The mean weight of the placentas from 68 women given pyrimethamine was $581 \pm 13.3 \mathrm{~g}$. $(20.5 \pm 0.47$ oz.), the corresponding weight in the control group of 69 women being $584 \pm 13.3 \mathrm{~g}$. $(20.6 \pm 0.47 \mathrm{oz}$.). There was thus no evidence that prevention of malaria affected the weight of the placenta. The placentas from 115 mothers receiving pyrimethamine were examined microscopically. Only one of these was found to contain a few malarial parasites. From the mothers on lactose tablets 105 placentas were examined and 18 showed malarial parasites. Of these mothers with infected placentas, one gave birth to twins, and another to a stillborn child whose sex was not recorded. In the remaining 17 the mean weight of the 13 singleton boys was $2,551 \mathrm{~g}$. ( $5 \mathrm{lb} .10 \mathrm{oz}$.), and of the four singleton girls $2,664 \mathrm{~g}$. ( $5 \mathrm{lb} .14 \mathrm{oz}$.).

\section{Discussion}

Although attention has often been drawn to the possible effects of malarial infection of the mother during pregnancy, few statistical records are available. The association of malarial parasites in the placenta and low birth weight has been the subject of four previous studies in Nigeria. Bruce-Chwatt (1952) first reported this association in Lagos. His findings were confirmed by Archibald (1956) at Ilaro, by Cannon (1958) at Ilesha in the Western Region, and by Spitz (1959) at Nsukka in the Eastern Region. These investigators found that the mean birth weight of infants born to a mother with a placenta infected with malarial parasites may be from $89 \mathrm{~g}$. $(2.9 \mathrm{oz}$.) to $311 \mathrm{~g}$. $(10 \mathrm{oz}$.) less than that of infants born to mothers with placentas free from parasites. In the last three of these reports informa- tion is given on the parity of the mother. The relationship to parity is important and the relevant data are summarized in Table III, which shows that more than one-third of the primiparous mothers in rural Nigeria are likely to have infected placentas. These mothers are more likely to produce lighter "premature" or stillborn infants.

TABLE III.-Incidence of Placentas Containing Malarial Parasites in Mothers of Different Parity

\begin{tabular}{|c|c|c|c|c|c|c|c|c|}
\hline \multirow{3}{*}{ Observer } & \multicolumn{8}{|c|}{ Parity } \\
\hline & \multicolumn{2}{|c|}{1} & \multicolumn{2}{|c|}{2} & \multicolumn{2}{|c|}{$3-5$} & \multicolumn{2}{|c|}{$6+$} \\
\hline & NM & Mal. & NM & Mal. & NM & Mal. & NM & Mal. \\
\hline $\begin{array}{l}\text { Archibald } \\
\text { (1956) } \\
\text { Cannon (1958) } \\
\text { Spitz (1959) }\end{array}$ & $\begin{array}{r}138 \\
45 \\
82 \\
\end{array}$ & $\begin{array}{l}35 \\
75 \\
47 \\
\end{array}$ & $\begin{array}{l}91 \\
41 \\
88 \\
\end{array}$ & $\begin{array}{l}15 \\
22 \\
30 \\
\end{array}$ & $\begin{array}{l}139 \\
133 \\
194 \\
\end{array}$ & $\begin{array}{l}15 \\
24 \\
46\end{array}$ & $\begin{array}{l}17 \\
43 \\
76 \\
\end{array}$ & $\begin{array}{r}1 \\
9 \\
12\end{array}$ \\
\hline Total $\quad$. & 265 & $\begin{array}{c}157 \\
(37 \%)\end{array}$ & 220 & $\begin{array}{c}67 \\
(23 \%)\end{array}$ & 466 & $\begin{array}{c}85 \\
(15 \%)\end{array}$ & 136 & $\begin{array}{c}22 \\
(14 \%)\end{array}$ \\
\hline
\end{tabular}

$\mathrm{NM}=$ Non-malarious. $\quad$ Mal. $=$ Malarious.

Infants born to primiparous mothers in all communities so far studied are lighter on the average than subsequent children. In Nigeria and other malarial areas there is probably an additional factor-namely, that the primiparous mother is more likely to have a placenta containing malarial parasites and with it an infant of low birth weight. In Nigeria the difference in mean birth weight between first and second infants was found to be $272 \mathrm{~g}$. (9.6 oz.) (Morley and Knox, 1960), whereas in England the difference was 119 g. (4.2 oz.) in male infants and 91 g. (3.2 oz.) in female infants (Martin, 1931). Table III suggests that there is a decreasing liability for the placenta to be infected with increasing parity of the mother.

In this study the mothers given pyrimethamine gained more weight during pregnancy than those in the control group. The babies born to such mothers in the treated group were heavier. This provides further evidence of the value of cheap regular suppressive malarial therapy suitable for pregnant women in regions where malaria is endemic. In this trial adequate suppression was apparently obtained with only two tablets $(50 \mathrm{mg}$.) of pyrimethamine monthly, and a single dose of four tablets $(600 \mathrm{mg}$.) of chloroquine if the mother came to the dispensary with fever. More frequent doses of pyrimethamine may be advocated ; however, if this means that the number of mothers who receive suppressive treatment has to be reduced, the total benefit to the community may be decreased. Although this method has been used during the past five years, pyrimethamineresistant strains of malarial parasites have not so far become apparent.

\section{Summary}

In an African village where malaria is holo-endemic, 429 pregnant women were divided into two groups. Those in the first group received $50 \mathrm{mg}$. of pyrimethamine monthly, and those in the second group similar tablets containing only lactose. All women were given a single dose of $600 \mathrm{mg}$. of chloroquine if they reported to the dispensary with fever.

The women in the treated group gained $852 \mathrm{~g}$. ( $1 \mathrm{lb} .14 \mathrm{oz}$.) more than the women in the control group during pregnancy.

Infants born to women in the treated groups had a birth weight $157 \mathrm{~g}$. $\left(5 \frac{1}{2} \mathrm{oz}\right.$.) greater than that of those in the control group.

Suppression of malaria had no apparent effect on the weight of the placenta.

\section{REFERENCES}

Archibald, H. M. (1956). Bull. Wld Hlth Org., 15, 842.

Bruce-Chwatt, L. J. (1952). Ann. trop. Med. Parasit., 46, 173. Cannon, D. S. H. (1958). Brit. med. F., 2, 877.

Covell, G., Coatney, G. R., Field, J. W., and Singh, J. (1955). Wld Hlth Org. Monogr. Ser., No. 27

Martin, W. J. (1931). Ann. Eugen., 4, 327.

Morley, D. (1963). Trans. roy. Soc. trop. Med. Hyg., 57, 79.

Morley, D. (193). (1960) Obstet. Gynaec. Brit. Cwlth, 67, 975.

Spitz, A. J. W. (1959). Bull. Wld Hlth Org., 21, 242. 